\title{
Strategi Komunikasi pada Dinas Kebudayaan dan Pariwisata dalam Mempromosikan Objek Wisata Kabupaten Banggai
}

\author{
Suanti Tunggala, Ken Amasita Saadjad \\ Fakultas Ilmu Sosial dan Ilmu Politik Universitas Muhammadiyah Luwuk \\ suantitunggala@gmail.com, Ken.sita@yahoo.co.id
}

Masuk tanggal : 19-11-2018, revisi tanggal : 26-08-2019, diterima untuk diterbitkan tanggal : 06-09-2019

\begin{abstract}
The purpose of this research is to find out the communication strategies at the Culture and Tourism Office in promoting Banggai Regency tourism objects, while the communication strategies that have been carried out at the Culture and Tourism Office in promoting Banggai Regency tourism objects through print, electronic and online media, but not yet innovative so that messages that reach the public and tourists are not optimal in disseminating information relating to attractions. The method that will be used in this research, namely the qualitative descriptive method, uses qualitative data analysis interactive models that begin with data collection, then performs data reduction, presents data by drawing conclusions and verifies then SWOT analysis, analyzes based on the strength of factors Internal factors include strengths and weaknesses, while external factors include opportunities and threats. While the population observed was all employees of the Banggai Regency Tourism Office numbering 49 people, where the determination of the sample in this study used a purposive sampling technique, with informants totaling 12 people. The results of this study, using a SWOT analysis matrix of internal and external factors, that the strength that can be utilized lies in the management of new attractions based on environmental sustainability (green investment), and the use of more innovative media. While the opportunity lies in recruiting civil servants in the fields of culture and tourism, improving the quality of human resources, increasing the operational budget in the promotion of tourism, by maximizing this it can avoid the threat
\end{abstract}

Keywords: communication strategy, promotion, tourism object, Banggai Regency Tourism Office

\begin{abstract}
Abstrak
Tujuan dalam penelitian ini, yakni untuk mengetahui strategi komunikasi pada Dinas Kebudayaan dan Pariwisata dalam mempromosikan objek wisata Kabupaten Banggai, adapun strategi komunikasi yang telah dilakukan pada Dinas Kebudayaan dan Pariwisata dalam mempromosikan objek wisata Kabupaten Banggai melalui media cetak, elektroknik, dan online, namun belum inovatif sehingga pesan yang sampai ke masyarakat dan wisatawan tidak optimal dalam menyebarluaskan informasi yang berkaitan dengan objek wisata. Adapun metode yang akan digunakan dalam penelitian ini, yakni dengan metode deskriptif kualitatif, menggunakan analisis data kualitatif model interaktif yang diawali dengan pengumpulan data, kemudian melakukan reduksi data, penyajian data dengan menarik kesimpulan dan melakukan verifikasi kemudian dilakukan analisis SWOT, menganalisa berdasarkan kekuatan faktor-faktor internal yang meliputi kekuatan dan kelemahan, sedangkan eksternal meliputi peluang dan ancaman. Sedangkan populasi yang diamati adalah seluruh pegawai kantor Dinas Pariwisata
\end{abstract}


Kabupaten Banggai berjumlah 49 Orang, dimana penentuan sampel dalam penelitian ini menggunakan teknik sampling purposive, dengan informan berjumlah 12 orang. Hasil penelitian ini, dengan menggunakan matriks analisis SWOT dari faktor internal dan eksternal, bahwa kekuatan yang dapat dimanfaatkan terletak pada pengelolaan objek wisata baru yang berbasis kelestarian lingkungan (green invesment), dan penggunaan media yang lebih inovatif. Sedangkan peluang terletak pada perekrutan PNS bidang kebudayaan dan pariwisata, peningkatan kualitas SDM, peningkatan anggaran operasional pada promosi pariwisata, dengan memaksimalkan hal ini maka dapat terhindar dari ancaman

Kata Kunci: strategi komunikasi, promosi, objek wisata, Dinas Kebudayaan dan Pariwisata Banggai

\section{Pendahuluan}

Di Indonesia, pariwisata telah menampilkan peranannya dengan nyata dalam memberikan kontribusi untuk kehidupan ekonomi, sosial dan budaya bangsa. Kesempatan kerja bagi orang-orang terampil di bidang ini makin bertambah jumlahnya, pendapatan negara dari sektor pajak dan devisa makin bertambah, keadaan sosial masyarakat yang terlibat dalam sektor ini makin baik, kebudayaan bangsa makin memperoleh apresiasi.

Menurut Undang-undang RI Nomor 10 Tahun 2009 tentang kepariwisataan Pasal 1 ayat 3, pariwisata adalah berbagai macam kegiatan wisata dan didukung oleh berbagai fasilitas serta layanan yang disediakan oleh masyarakat, pengusaha, pemerintah dan Pemerintah Daerah. Salah satu prinsip terselenggaraanya kepariwisataan adalah memberikan manfaat untuk kesejahteraan rakyat, keadilan, kesetaraan, dan proporsionalitas. berdasarkan prinsip tersebut, maka sektor pariwisata dapat menjadi salah satu sektor yang berpotensi sebagai sumber perekonomian untuk dikembangkan, dimana data dari Kementerian Pariwisata dan Ekonomi Kreatif (Kemenparekraf, 2015). Tentang jumlah kunjungan wisatawan mancanegara pada bulan Februari 2015 sebanyak 786.653 kunjungan atau mengalami pertumbuhan sebesar 11.95 persen. Terdapat beberapa upaya untuk dapat meningkatkan jumlah kunjungan wisatawan, salah satunya adalah melalui strategi komunikasi dalam mempromosikan objek wisata, sebagaimana yang dinyatakan oleh Seyitoglu \& Yuzbasioglu dalam Pratiwi, Dida, \& Sjafirah (2018) bahwa Ssrategi komunikasi bertujuan meyakinkan opini publik juga membentuk sikap dan perilaku masyarakat. Dalam hal ini, komunikasi menjadi sangat penting untuk memulai jalannya suatu program atau kegiatan.

Sedangkan menurut Kennedy dan Soemanegara dalam Ilmiah et al (2016) tujuan komunikasi pemasaran adalah untuk mencapai tiga tahap perubahan yaitu :

a. Perubahan pengetahuan dalam tahap ini perusahaan memberikan pengetahuan pada konsumen tentang keberadaan produk, bentuk produk untuk apa produk itu diciptakan dan ditujuan kepada siapa.

b. Perubahan sikap yang mengarah kepada keinginan untuk mencoba produk. Pada tahap ini ditentukan oleh tiga komponen yaitu: 1) efek kognitif, membentuk kesadaran informasi tertentu yang mengakibatkan perubahan pada aspek pengetahuan, kepercayaan atau keyakinan; 2) efek afeksi yaitu 
memberikan pengaruh untuk melakukan sesuatu yang diharapkan adalah realisasi pembelian; 3) efek konatif yaitu membentuk pola khalayak menjadi perilaku selanjutnya. Yang diharapkan adalah pembelian ulang.

c. Perubahan perilaku dimaksudkan agar konsumen tidak beralih ke produk lain dan terbiasa menggunakannya.

Dalam dunia kepariwisataan segala sesuatu yang menarik dan bernilai untuk dikunjungi dan akan dilihat di sebut "atraksi" atau lazim pula dinamakan objek wisata" atraksi atau objek wisata, baik hadir secara natural, maupun yang biasa berlangsungnya setiap hari serta khusus diadakan pada waktu tertentu. Sedangkan daerah wisata atau yang biasa disebut "daerah tujuan wisata" merupakan daerah yang memiliki objek wisata yang memikat sebagai tujuan kunjungan wisata. Dimana, objek tersebut antara lain: panorama keindahan alam yang menakjubkan seperti gunung, lembah, air terjun, danau, pantai, matahari terbit, cuaca, udara, dan lain-lain yang berkaitan dengan keadaan alam sekitarnya. Disamping itu ada juga yang merupakan budaya hasil ciptaan manusia seperti monumen, candi, bangunan klasik, peninggalan purbakala, museum, arsitektur kuno, seni tari, musik/gamelan, agama, adat istiadat, upacara, pekan raya, peringatan/perayaan, pertandingan, pameran/kegiatan-kegiatan budaya, sosial yang bersifat khusus yang menonjol dan meriah.

Hal tersebut diatas merupakan potensi pariwisata yang jika dikembangkan dengan tepat dapat menjadi salah satu sumber pendapatan negara yang besar. Selain itu potensi tersebut didukung oleh pernyataan World Tourism Organization (WTO) bahwa terdapat kecenderungan semakin besarnya minat dan preferensi masyarakat baik global, regional maupun nasional untuk dapat mengkonsumsi barang dan jasa yang bersifat alami (DBA 1998 dalam Tami, 2013). Dalam hal ini, pariwisata merupakan fenomena kemasyarakatan, yang menyangkut manusia, masyarakat, kelompok, organisasi, kebudayaan, dan sebagainya, yang merupakan objek kajian sosiologi. Namun demikian kajian sosiologi belum begitu lama dilakukan terhadap pariwisata, meskipun pariwisata sudah mempunyai sejarah yang sangat panjang. Hal ini terkait dengan kenyataan bahwa pariwisata pada awalnya lebih dipandang sebagai kegiatan ekonomi, namun tujuan utama pengembangan pariwisata adalah untuk mendapatkan keuntungan ekonomi, baik bagi masyarakat maupun negara.

Oleh karena itu, pariwisata dapat dilihat sebagai suatu lembaga dengan banyak sekali interaksi, kebudayaan dengan sejarahnya, kumpulan pengetahuan, dan jutaan orang yang merasa dirinya sebagai bagian dari kelembagaan ini, sehingga pariwisata sebagai konsep dapat di pandang dari berbagai perspektif yang berbeda. Sejalan dengan semangat Otonomi Daerah dan Peraturan Pemerintah RI No.25 Tahun 2000 tentang Kewenangan Provinsi sebagai Daerah Otonom, salah satu pasal dalam Peraturan Pemerintah tersebut mengatur kewenangan daerah otonom dalam bidang budaya dan pariwisata. Di dalam pasal tersebut ditentukan bahwa daerah otonom dapat melakukan promosi dalam rangka meningkatkan jumlah arus kunjungan wisatawan ke daerahnya masing-masing. 
Untuk melakukan promosi diperlukan adanya upaya pemahaman mendalam mengenai pasar yang kemudian menjadi dasar dalam penyusunan strategi dan program promosi. Sebagaimana Swastha (2001) menyatakan bahwa promosi dipandang sebagai kegiatan komunikasi pembeli dan penjual dan merupakan kegiatan yang membantu dalam pengambilan keputusan di bidang pemasaran serta mengarahkan dan menyadarkan semua pihak untuk berbuat lebih baik. Tjiptono (2001) dalam Rizky \& Yasin (2014) mendefinisikan promosi sebagai aktivitas pemasaran yang berusaha menyebar informasi, mempengaruhi/ membujuk, dan/atau mengingatkan pasar sasaran atas perusahaan agar bersedia menerima, membeli dan loyal pada model perumahan yang ditawarkan perusahaan yang bersangkutan. Pemasaran yang dikaitkan dengan industri dan obyek wisata, dalam bahasa Inggris disebut dengan berbagai istilah, tergantung pada jenis kegiatan promosi yang diselenggarakan seperti : exhibition, expo atau exposition, industrial show, tradefair, trade show, professional/scientific exhibition. Kegiatan promosi tersebut dapat didukung oleh media, sebagaimana menurut McQuil (2002) dalam Burhan Bungin (2009), menyatakan bahwa media massa merupakan institusi yang menghubungkan seluruh unsur masyarakat satu dengan lainnya dengan melalui produk media massa yang dihasilkan. Secara spesifik institusi media massa adalah (1) sebagai saluran produksi dan distribusi konten simbolis; (2) sebagai institusi publik yang bekerja sesuai aturan yang ada; (3) keikutsertaan baik sebagai pengirim atau penerima adalah sukarela; (4) menggunakan standar profesional dan birokrasi; (5) media sebagai perpaduan antara kebebasan dan kekuasaan.

Adanya media massa dalam mempromosikan objek wisata, maka komunikasi yang efektif membutuhkan strategi publisitas yang merupakan seluruh kesatuan metode dengan mempergunakan berbagai macam media sebagai alat yang dibantu oleh faktor psikologis, statistik sosiodemografi dan penelitian untuk menyebarkan gagasan-gagasan, menjual hasil produk dan menjadikan organisasi dikenal. Seperti halnya mengoptimalkan gimmick (tipu-muslihat) wisata mereka melalui media massa cetak dan elektronika serta media online dengan motto masing-masing.

Untuk itu, penggunaan media cetak dan elektronika serta media online merupakan strategi komunikasi dalam promosi objek wisata, dimana tujuannya bukan hanya untuk memberitahukan, melainkan membujuk wisatawan, supaya wisatawan yang bersangkutan mempunyai keinginan untuk datang berkunjung ke daerah yang telah dipromosikan. Oleh karena itu promosi harus dilakukan melalui media komunikasi yang efektif, sebab orang-orang yang menjadi sasaran promosi mempunyai selera dan keinginan yang berbeda-beda.

Seperti halnya pada Dinas Pariwisata dalam melakukan strategi komunikasi untuk mempromosikan objek wisata Kabupaten Banggai dengan menggunakan metode strategi publisitas melalui internet (web.diskepar.kabupatenbanggai.go.id), yang menerbitkan brosur, leaflet, postcard, baliho yang berbingkai, standing banner, rolling banner, neon box, televisi (TVRI dan TV Luwuk Banggai), radio (radio FM. Setia Nada), surat kabar (Luwuk Post) serta berpartisipasi di dalam event internasional, nasional, dan regional yang berkaitan dengan publikasi objek wisata, namun pelaksanaannya 
Suanti Tunggala, Ken Amasita Saadjad: Strategi Komunikasi pada Dinas Kebudayaan dan Pariwisata dalam Mempromosikan Objek Wisata Kabupaten Banggai

tidak optimal sampai ke masyarakat dan wisatawan karena jangkauannya sangat terbatas dan penggunaan medianya belum inovatif, sehingga pesannya tidak menyebarluas. Adapun asumsi sementara dari hasil identifikasi masalah dari penelitian ini adalah sebagai berikut :

1. Strategi komunikasi pada Dinas kebudayaan dan Pariwisata, membutuhkan metode yang efektif dalam mempromosikan objek wisata Kabupaten Banggai.

2. Penggunaan media cetak, elektronik, dan online belum inovatif, sehingga pesan yang sampai ke masyarakat dan wisatawan tidak optimal karena pesannya tidak menyebarluas.

Berdasarkan hasil identifikasi pada penelitian ini, maka rumusan masalah yang dikaji dalam penelitian ini, yakni mengenai bagaimana strategi komunikasi pada Dinas Kebudayaan dan Pariwisata dalam mempromosikan Objek Wisata Kabupaten Banggai, maka pendekatan yang tepat dalam mengkaji dengan menggunakan pendekatan Analisis SWOT, dimana dapat memaksimalkan kekuatan (strength) dan peluang (opportunities), namun secara bersamaan dapat meminimalkan kelemahan (weakness) dan ancaman (threats). (Freddy Rangkuti 2009)

Berdasarkan uraian latar belakang tersebut, maka peneliti tertarik untuk mengkaji dengan melakukan penelitian yang berjudul "Strategi Komunikasi pada Dinas Kebudayaan dan Pariwisata dalam Mempromosikan Objek Wisata Kabupaten Banggai.

\section{Metode Penelitian}

Penelitian ini, dilaksanakan pada Dinas Kebudayaan dan Pariwisata Kabupaten Banggai. Adapun waktu dalam pelaksanaan penelitian ini, dilakukan maksimal selama 1 tahun (12 bulan) yang akan dimulai bulan Januari 2018 dan berakhir di bulan Desember 2018, sedangkan minimal dari waktu pelaksanaan penelitian ini, dilakukan selama 6 bulan, yang dimulai dari bulan Juli sampai dengan bulan Desember 2018.

Jenis Penelitian ini adalah penelitian deskriptif kualitatif dengan fokus penelitian adalah strategi komunikasi apa yang digunakan oleh Dinas Kebudayaan dan Pariwisata dalam mempromosikan objek wisata Kabupaten Banggai, sehingga pesan yang sampai ke masyarakat dan wisatawan dapat maksimal (optimal) karena pesannya bisa menyebarluas. yakni:

Sedangkan data yang diperlukan dalam penelitian ini untuk dianalisis

1) Data primer adalah data yang diperoleh dalam penelitian secara langsung terhadap objek yang diteliti melalui hasil wawancara terhadap informan yang berdasarkan dengan pedoman wawancara yang berkaitan dengan topik penelitian ini.

2) Data sekunder adalah data yang diolah atau diperoleh dari berbagai sumber literatur, dokumentasi, dan informasi dari pihak terkait yang berhubungan dengan permasalahan dalam penelitian ini. 
Adapun populasi dalam penelitian ini adalah wilayah generalisasi yang terdiri atas: bbyek/subyek yang mempunyai kualitas dan karakteristik tertentu yang ditetapkan oleh peneliti untuk dipelajari dan kemudian ditarik kesimpulannya, (Sugiyono, 2011), sehingga yang menjadi populasi dalam penelitian ini adalah seluruh Pegawai Kantor Dinas Kebudayaan dan Periwisata yang berjumlah 21 Orang Pegawai Tidak Tetap (Honorer) dan 28 Orang Pegawai Tetap dengan total keseluruhan populasi berjumlah 49 Orang.

Untuk teknik penentuan sampel pada penelitian ini menggunakan teknik sampling purposive sampling, dimana teknik penentuan sampel dengan pertimbangan tertentu (Sugiyono, 2011). Memilih informan yang memiliki karakteristik tertentu yang relevan dengan penelitian ini. Adapun informan dalam penelitian adalah pegawai tetap pada Kantor Dinas Pariwisatayang berjumlah berjumlah 12 orang yaitu: Kepala Dinas Kebudayaan dan Pariwisata, Kepala Bidang Destinasi Pariwisata, Kepala Bidang Pemasaran Pariwisata, Staf Bidang Pengembangan Ekonomi Kreatif, Kepala Seksi Pengembangan Pasar dan Informasi Pariwisata, Kepala Seksi Pembangunan dan Pelestarian Daya tarik wisata, Kassubbag. Umum dan Kepegawaian, Kasubbag. Perencanaan dan Evaluasi. Staf bidang Keuangan 2 (orang) dan Staf Pemasaran Pariwisata 2 (orang).

Teknik pengumpulan data dalam penelitian ini menggunakan beberapa metode untuk dapat memperdalam penelitian diantaranya melalui penelitian kepustakaan yakni penelitian yang dilakukan dengan mengumpulkan data dari literatur dan mempelajari buku-buku petunjuk teknis serta teori-teori yang dapat digunakan sebagai bahan penelitian ini dan bahan pendukung dalam penelitian.

Penelitian lapangan memiliki pendekatan yang lebih bersifat kualitatif, sangat mengandalkan pada data lapangan yang diperoleh melalui informan, responden, dokumentasi atau observasi pada setting sosial yang berkaitan dengan subyek yang diteliti. Dalam pelaksanaannya, peneliti mengamati responden secara langsung dan berpartisipasi di dalam setting sosial, serta menyatu dengan budaya yang ada. Teknik pengamatannya dapat dilakukan dengan percakapan, wawancara terstruktur (formal), wawancara tidak terstruktur (informal), survey dan pengumpulan dokumen-dokumen pribadi (tulisan, rekaman percakapan, foto, dan lain-lain). (Nurdiani, 2014).

Dalam penelitian ini, menggunakan analisis data kualitatif Model Interaktif, berdasarkan pendapat Matthew B. Miles dan A. Michael Huberman (dalam Sugiyono, 2009) yang dapat digambarkan sebagai berikut :

1. Pengumpulan data adalah tahap megumpulkan data yang diperoleh dari hasil wawancara, observasi, penelitian kepustakaan dan dokumentasi sertadata sekunder lainnya yang berhasil di peroleh.

2. Reduksi Data. Proses reduksi diartikan sebagai proses pemilihan, pemusatan perhatian pada penyederhanaan, pengabstrakan dan transformasi data "kasar" yang muncul dari catatan-catatan tertulis di lapangan. Proses reduksi data bukanlah proses yang sekali jadi, tetapi sebuah proses yang berulang selama proses penelitian kualitatif berlangsung. Data yang diperoleh di lapangan kemudian direduksi oleh peneliti dengan cara pengkodean, klasifikasi data, menelusuri tema-tema, membuat gagasan, 
menulis memo, dan selanjutnya dilakukan pilihan terhadap data yang diperoleh dilapangan, kemudian dari data itu mana yang relevan dan mana yangtidak relevan dengan permasalahan dan fokus penelitian. Reduksi data atau proses transformasi ini berlanjut terus sesudah penelitian lapangan, sampai laporan akhir secara lengkap tersusun.

3. Penyajian Data. Langkah berikutnya setelah proses reduksi data berlangsung adalah penyajian data yang dimaknai sebagai sekumpulan informasi yang tersusun yang memberi kemungkinan adanya penarikan kesimpulan dan pengambilan tindakan, dengan mencermati penyajian data ini, maka akan dapat dipahami apa yang sedang terjadi dan apa yang harus dilakukan. Artinya meneruskan analisisnya atau mencoba untuk mengambil sebuah tindakan dengan memperdalam temuan tersebut. Hal ini dilakukan untuk memudahkan bagi peneliti melihat gambaran secara penelusuran. Penjelasan yang dipaparkan berikut sesuai dengan hasil pengumpulan data dilapangan dengan menjabarkan beberapa strategi komunikasi dan Optimalisasi penggunaan media pada Dinas Pariwisata dalam mempromosikan objek wisata Kabupaten Banggai.

4. Analisis SWOT. Pendekatan Analisis Swot, merupakan pendekatan yang dapat memaksimalkan kekuatan (strength) dan peluang (opportunities), namun secara bersamaan dapat meminimalkan kelemahan (weakness) dan ancaman (threats) (Freddy Rangkuti, 2009). Penelitian ini, menganalisa berdasarkan kekuatan faktor-faktor internal yang meliputi kekuatan dan kelemahan, sedangkan eksternal meliputi peluang dan ancaman, yang kemudian dianlisa dengan skoring sehingga dapat terbentuk ranking dan dikaji berdasarkan analisis matriks internal - eksternal digunakan untuk mempertajam hasil evaluasi faktor-faktor tersebut dan berguna untuk mengetahui strategi komunikasi pada Dinas Pariwisata dalam mempromosikan objek wisata Kabupaten Banggai.

\section{Hasil Penemuan dan Diskusi}

Strategi komunikasi merupakan rangkaian aktivitas berkelanjutan dan koheren yang sistematis, dilakukan secara taktis, yang memungkinkan pemahaman terhadap khalayak sasaran, mengidentifikasi saluran yang efektif, dan mengembangkan dan mempromosikan gagasan dan opini melalui saluran tersebut dalam rangka mempromosikan dan mempertahankan jenis perilaku tertentu (Pratiwi et al., 2018). Definisi ini mengindikasikan bahwa strategi komunikasi digunakan sebagai alat untuk mengubah perilaku dan diperlukan perencanaan dalam mencapai tujuan strategi komunikasi tersebut (Pratiwi et al., 2018). Salah satu tujuan tersebut adalah branding, dimana sebuah produk dapat menarik konsumen jika mempunyai merk (brand). Branding memiliki tempat di benak konsumen. Branding bukanlah pertarungan untuk menentukan siapa yang dapat membuat produk lebih baik, akan tetapi siapa yang dapat menciptakan persepsi lebih baik (Nasrullah, 2015). 
Berbicara mengenai batasan dari pengertian strategi secara umum, maka dalam penelitian ini dapat diuraikan konsep tentang strategi komunikasi pada Dinas Pariwisata dalam mempromosikan objek wisata Kabupaten Banggai. Hal ini dapat dianalisis dengan mempergunakan analisis SWOT (Strenght = Kekuatan, Weakness = Kelemahan, Opportunity $=$ Peluang, Treath $=$ Ancaman $),($ Freddy Rangkuti, 2009). Dimana pelaksanaan analisis tersebut dilakukan dengan penentuan elemen kekuatan, kelemahan, peluang, dan ancaman. Hal ini diklasifikasikan ke dalam faktor internal dan dan eksternal.

Adapun faktor internal dan eksternal yang ditemukan dalam penelitian ini melalui hasil wawancara kepada informan yang berjumlah 12 orang pegawai Dinas Pariwisata Kabupaten banggai, mengenai strategi komunikasi pada Dinas Pariwisata dalam mempromosikan objek wisata yang ada di Kabupaten Banggai dengan menggunakan alat analisis SWOT yang penggambarannya, melihat kondisi lingkungan internal dan eksternal yang dapat dirumuskan pada faktor internal dan eksternal yang indikatornya dapat di kemukakan pada tabel 1 berikut ini :

Tabel 1. Ringkasan Analisis Faktor-Faktor Internal dan Eksternal Dinas Pariwisata Kabupaten Banggai

\begin{tabular}{l} 
Faktor-Faktor Strategis Internal \\
\hline Kekuatan: \\
a. Partisipasi wisatawan \\
b. Ketersediaan penggunaan media cetak \\
$\quad$ \& elektronik (online) \\
c. Potensi objek yisata \\
d. Kualitas pelayanan informasi
\end{tabular}

\section{Faktor-Faktor Strategis Eksternal} Peluang :

a. Lokasi wisata yang belum dikelola dengan maksimal

b. Meningkatkan pendapatan masyarakat

c. Membangun mitra dengan stakeholder
Kelemahan :

a. Kuantitas SDM

b. Kualitas SDM

c. Kuantitas \& kualitas usaha jasa dan sarana wisata

d. Kualitas destinasi
Ancaman :
a. Kualitas sarana \& prasarana wisata
b. Pengelolaan objek wisata oleh pihak swasta/perorangan
c. Kondisi iklim yang ekstrim dilokasi objek wisata

Berdasarkan tabel 1, diatas bahwa didalam penelitian ini, dapat diuraikan faktor-faktor strategi internal pada Dinas Pariwisata dalam mempromosikan objek wisata Kabupaten Banggai yang terdiri dari :

1. Kekuatan yang dimiliki oleh Dinas pariwisata yakni antara lain:

a. Partisipasi wisatawan, hal ini dapat dikaji dengan meningkatnya minat kunjungan wisatawan lokal maupun wisatawan mancanegara dimana respon masyarakat setempat, khususnya dapat dilihat melalui kehadiran di dalam kegiatan yang diselenggarakan oleh pihak pemerintah khususnya Dinas Pariwisata melalui event festival budaya sebagai bagian dari promosi pariwisata seperti festival Teluk Lalong yang di bulan juni 2018. Sedangkan pada wisatawan manca negara, seperti wisatawan asing yang berasal dari Belanda dan Inggris, telah menjadikan sebuah objek dalam 
pembuatan film dokumenter yang salah satunya objek wisata pulo dua yang ada di Kabupaten Banggai.

b. Ketersediaan penggunaan media cetak dan media elektronik (online), dalam mempromosikan objek wisata dikabupaten Banggai. Sebagaimana Hasil dari penelitian sebelumnya oleh Lukita \& Sunarto (2017) adalah Kementerian Pariwisata melaksanakan peran yang sama dengan Public Relations dalam mengkampanyekan Taman Nasional Komodo melalui brand Pesona Indonesia dengan menggunakan media massa, media sosial dan kampanye Public Relation. Pada saat ini Kementrian Pariwisata lebih memusatkan aktifitas penggunaan media sosial dan publikasi melalui travel blogger untuk mengkampanyekan Taman Nasional Komodo untuk memberikan informasi dan mempersuasif para masyarakat Indonesia untuk menjadi wisatawan nusantara yang berkunjung ke Taman Nasional Komodo. Hal itu juga dapat ditunjukkan pada penelitian ini bahwa peneliti menemukan media-media tersebut yang digunakan oleh dinas pariwisata kabupaten Banggai melalui yakni, leaflet, brosur, postcard, baliho yang berbingkai, standing banner, rolling banner, neon box, yang mana media cetak tersebut disebarkan diberbagai tempat seperti di hotel-hotel, bandara, warung makan, restoran dan tempat-tempat yang disesuaikan dengan bentuk media cetak yang ada. Pada media koran melalui media Banggai Raya, Luwuk Post, Metro Luwuk, dan Banggai Ekspo, serta adanya stand dalam pameran, pajangan dalam etalase. Sebagaimana Hasil dari penelitian sebelumnya oleh Yunita \& Paramita (2017) bahwa perlunya strategi komunikasi yang dilakukan pada museum terutama Galeri Nasional Indonesia melalui pameran. Sedangkan media elektronik dengan jaringan internet (digital) melalui jejaring sosial yang berbasis ICT dengan website, FaceBook, WA, Email, Instagram dan media televisi misalnya web supertama.com ini sejak bulan Oktober 2015, diantaranya ada tulisan dengan judul tulisan "Luwuk di Lubuk Hati", "Cinta Segitigaku di Luwuk", "Bangga di Banggai", "Menanti Kilo Lima menjadi Bintang-5", "Dimana itu Luwuk", “Antara Luwu dan Luwuk, fanpage BTB (Banggai Tourism Board) dengan nama akun VisitLUWUK juga fanpage GarudaIndonesiaLUWUK. Serta Trans TV pernah melakukan tayangan/ siaran langsung mengenai objek wisata yang ada dikabupaten banggai melalui acara petualangan seperti My Trip My Advanture, dan Sibolang.

Sebagaimana halnya pada penelitian sebelumnya pada Dinas Pariwisata dan Kebudayaan kota Pariaman yang menentukan segmentasi dalam memperkenalkan tempat wisata pantai Gandoriah menetapkan target pengunjungnya dan membuat sebuah tage line "Ayokepariaman" yang memiliki makna mengajak orang untuk dapat datang ke Kota Pariaman. Dengan menggunakan beberapa media yakni: event, booklet, media sosial, website dan brosur. (Rozi, 2018)

c. Potensi objek, adapun objek wisata alam dan wisata bahari serta wisata buatan yang telah dipromosikan kepada masyarakat antara lain terdiri dari; pantai Kilo Lima, Air Terjun Salodik, Pulo Dua Balantak, Air Terjun 
Tontowan, sedangkan kegiatan promosi objek wisata budaya seperti hari nusantara pada tanggal 12 desember 2014 dengan menyelenggarakan pameran pangan lokal, fashion show dan tari-tarian khas kabupaten banggai. Festival Pulo Dua Balantak yang kegiatannya pada tahun 2017, melalui rangkaian atraksi seperti mendaki gunung, terjun payung dan menyelam.

d. Kualitas pelayanan informasi, memberikan kualitas pelayanan yang prima kepada pengunjung wisata yang secara langsung mendatangi kantor Dinas Pariwisata Kabupaten Banggai dengan selalu memberikan informasi yang benar-benar sesuai dengan kondisi tempat atau lokasi wisata maupun sarana dan prasarana serta akomodasi di lokasi objek wisata yang akan dikunjungi oleh wisatawan.

2. Kelemahan yang dimiliki oleh Dinas pariwisata yakni antara lain:

a. Kuantitas SDM, dengan adanya kekosongan jabatan struktural organisasi yang ada dikantor Dinas Pariwisata Kabupaten Banggai, salah satunya kekosongan kepala seksi peningkatan kapasitas SDM Pariwisata memberikan dampak negatif sehingga dapat menghambat jalannya visi dan misi, serta sasaran yang akan dicapai oleh Dinas Pariwisata, dimana didalam menjalankan tufoksi tidak akan berjalan secara maksimal karena tufoksi pada seksi peningkatan kapasitas SDM Pariwisata tersebut akan diambil alih oleh seksi yang lain yang telah mempunyai tufoksi sebelumnya.

b. Kualitas SDM, dengan adanya taraf pendidikannya yang masih kurang, dapat mempengaruhi pengetahuannya dalam mengaplikasikan segala aktivitas perkantoran yang ada pada Dinas Pariwisata Kabupaten Banggai dan masih kurangnya kesadaran untuk disiplin kerja dalam kehadirannya dikantor oleh sebab itu banyak aktivitas yang terhambat atau tertunda. Serta kegiatan Pelatihan yang sangat minim bagi para pegawai kantor Dinas Pariwisata Kabupaten Banggai.

c. Kuantitas \& kualitas usaha jasa dan sarana wisata, tidak adanya pemandu wisata pada usaha jasa pariwisata sedangkan sarana wisata pada transportasi seperti halnya mobil bus pariwisata belum dimanfaatkan dengan maksimal dan tepat terhadap kebutuhan para wisatawan. Serta tidak adanya pemeliharaan yang maksimal terhadap sarana wisata seperti kamar ganti, ruang jaga dan kamar mandi (MCK). Sebagaimana penelitian sebelumnnya oleh Christiani N.T \& Setyanto (2017), bahwa infrastruktur sangat penting bagi pengembangan objek wisata Bukit Kasih, dan partisipasi masyarakat dalam mendukung pengembangan pariwisata di Bukit Kasih yang mengatakan bahwa Pemerintah Kabupaten Minahasa, khususnya Dinas Pariwisata dinilai lamban dalam menindaklanjuti pengembangan di Bukit Kasih.

d. Kualitas destinasi, menyangkut mengenai dana sebagai anggaran dalam pemasaran objek wisata, namun kenyataan yang ada bahwa anggaran yang telah disediakan oleh pemerintah daerah tidak sesuai dengan perencanaan operasional, serta pengembangan pemasaran objek wisata. 
Suanti Tunggala, Ken Amasita Saadjad: Strategi Komunikasi pada Dinas Kebudayaan dan Pariwisata dalam Mempromosikan Objek Wisata Kabupaten Banggai

Sedangkan faktor-faktor strategi eksternal pada Dinas Pariwisata dalam mempromosikan objek wisata Kabupaten Banggai yang terdiri dari :

1. Peluang, yang dimiliki oleh Dinas pariwisata yakni antara lain:

a. Lokasi wisata yang belum dikelola dengan maksimal

Kota Luwuk sebagai ibu kota Kabupaten Banggai, juga mempunyai banyak tempat wisata mulai dari air terjun, perbukitan, padang savana dan gua alami serta tempat wisata buatan. Jumlah air terjun di Luwuk tak terbilang jumlahnya antara lain air terjun Arjuna, Piala, Laumarang, Dendengan dan Salodik tersebar di beberapa kecamatan di kabupaten Banggai. Perbukitan indah tersebar di Luwuk antara lain bukit Kasih Sayang dan bukit Teletubbies. Padang savana ala Amerika terdapat di desa Lenyek, sekitar 1 jam perjalanan dari kota Luwuk yang pernah diulas oleh satu media online nasional. Berbagai jenis gua alami tersebar di sejumlah desa di Luwuk. Tempat wisata buatan di Luwuk antara lain bendung Mentawa dengan air bening mengalir dihiasi deretan rapi pohon pinus di desa Mentawa kecamatan Toili Barat. Adapun objek wisata lain yang belum dikelola secara maksimal, beberapa contoh lokasi wisata yang dimaksud antara lain mulai dari pantai Pandan Wangi, pantai Minahaki yang baru saja trending di sosial media dengan nama Cemara Seribu karena pantai ini ditumbuhi pohon cemara alami yang cocok untuk tempat liburan keluarga termasuk untuk berkemah, pantai Kilo Lima di dekat kota Luwuk, pantai Bilalang, desa wisata Uwedikan, Pulo Dua serta puluhan pantai lainnya dengan keunikan dan kecantikan tersendiri yang belum banyak dieksplor dan terpublikasikan. Kesemua dari objek wisata tersebut sama sekali belum dikelola oleh Dinas Pariwisata Kabupaten Banggai sehingga diharapkan kedepan ini dapat dikelola sehingga akan menjadi objek wisata baru yang akan menambah animo wisatawan domestik dan mancanegara untuk mengunjungi Kabupaten Banggai.

b. Meningkatkan pendapatan masyarakat, keberadaan lokasi atau tempattempat wisata yang ada di kabupaten Banggai sebagai objek wisata dapat mempengaruhi tingkat ekonomi masyarakat sekitar, dimana dapat menambah mata pencaharian masyarakat disekitar lokasi wisata. Seperti objek wisata bahari pantai Kilo Lima sangatlah berpengaruh terhadap tingkat pendapatan dan mata pencaharian masyarakat, sehingga hal ini menjadi sebuah peluang untuk pemerintah daerah khususnya pada dinas pariwisata ke depanya agar lebih memperhatikan objek-objek wisata yang ada dengan mempromosikan objek wisata agar dapat dimanfaatkan dan lebih dikelola dengan maksimal sehingga dengan tidak secara langsung dapat membuka peluang untuk masyarakat sekitar lokasi wisata untuk merubah kondisi perekonomiannya yang lebih baik.

c. Membangun mitra dengan stakeholder. Dalam hal ini, Pemkab Banggai telah membentuk Badan Promosi Pariwisata Daerah yang dinamai BTB atau Banggai Tourism Board dengan tugas utama bersinergi dengan Dinas Pariwisata setempat untuk mempromosikan potensi pariwisata di kota Luwuk, dan di dalam kabupaten Banggai maupun di luar negeri pada berbagai pameran pariwisata antara lain di ajang Garuda Indonesia Travel 
Fair dan Deep \& Extreme di Jakarta Convention Center tahun 2017, telah disusun oleh BTB berbagai kegiatan wisata dalam Calender of Event dan kemungkinan akan terealisasi dengan maksimal dengan dukungan pendanaan. Hal ini dapat didukung melalui hasil penelitian sebelumnya oleh Pratiwi, Dida, Sjafirah (2018) yang menunjukkan bahwa wisata halal di Kota Bandung dikembangkan melalui dukungan dari berbagai lintas lembaga, yang disebut strategi penta helix. Strategi komunikasi yang dilakukan oleh Dinas Pariwisata dan Kebudayaan Provinsi Jawa Barat dalam mempersiapkan Kota Bandung sebagai destinasi wisata halal dengan melakukan sosialisasi untuk menumbuhkan kesadaran (awareness) kepada SKPD terkait. Selain Dinas Pariwisata dan Kebudayaan Provinsi Jawa Barat, beberapa lembaga lain seperti Enhaii Halal Tourism Center (EHTC) dan Salman Halal Center melakukan awareness building kepada para pemangku kepentingan dan juga masyarakat. Diperlukan strategi komunikasi yang lebih kompleks untuk mengkomunikasikan wisata halal kepada stakeholders dan juga masyarakat.

2. Ancaman, yang dimiliki oleh Dinas pariwisata yakni antara lain:

a. Kualitas sarana \& prasarana wisata masih minin dan belum diperbaiki. Aspek ini dinilai lemah karena dibeberapa tempat wisata yang ada masih belum terdapat sarana pendukung seperti kamar mandi, penginapan, air bersih, serta kios atau warung sehingga pengunjung yang datang harus membawa persediaan yang dibutuhkan selama mereka berada di lokasi wisata tersebut. Kelemahan pada aspek dari kualitas dan prasarana wisata tersebut, akan menjadi ancaman pada strategi komunikasi dalam mempromosikan objek wisata kabupaten banggai, misalnya Minahaki Toili dan Pulo Dua.

b. Pengelolaan objek wisata oleh pihak swasta/perorangan, yakni adanya pengelolaan objek wisata permandian Sandakan yang merupakan milik perseorangan dan telah menjadi ancaman terhadap ketertarikan wisatawan dilokasi objek wisata yang dikelola oleh Dinas pariwisata Kabupaten Banggai.

c. Kondisi iklim yang ekstrim dilokasi objek wisata. Adapun objek wisata bahari yang sangat membutuhkan dukungan dari kondisi alam karena kalau musim angin akan terjadi ombak dilautan. Kondisi tersebut akan menjadi kendala untuk bisa sampai ketempat objek wisatawan dan tidak mendukung aktivitas di lokasi objek wisata, karena harus menyeberangi lautan dengan menggunakan perahu/sampan, maupun speed, seperti pulau Pulau Dua Balantak, Pulau Tinalapu, serta permandian Salodik salah satu objek wisata yang kondisinya terjal dan curam.

Berdasarkan uraian dari tabel 1, maka peneliti dapat menemukan hasil penelitian ini tentang stategi komunikasi pada Dinas Pariwisata dalam mempromosikan objek wisata Kabupaten Banggai dalam matriks analisis SWOT pada tabel 2, berikut ini: analisis dari kondisi lingkungan internal (kekuatan, kelemahan) dan kondisi lingkungan eksternal (peluang, ancaman) terhadap promosi objek wisata yang dilaksanakan oleh Dinas Pariwisata Kabupaten 
Suanti Tunggala, Ken Amasita Saadjad: Strategi Komunikasi pada Dinas Kebudayaan dan Pariwisata dalam Mempromosikan Objek Wisata Kabupaten Banggai

Banggai. Strategi-strategi tersebut dengan menggunakan matriks SWOT terlihat pada bagan, dengan tabel 2 berikut ini:

Tabel 2. Matriks SWOT Perumusan Strategi Komunikasi pada Dinas Pariwisata dalam promosi objek wisata Kabupaten Banggai

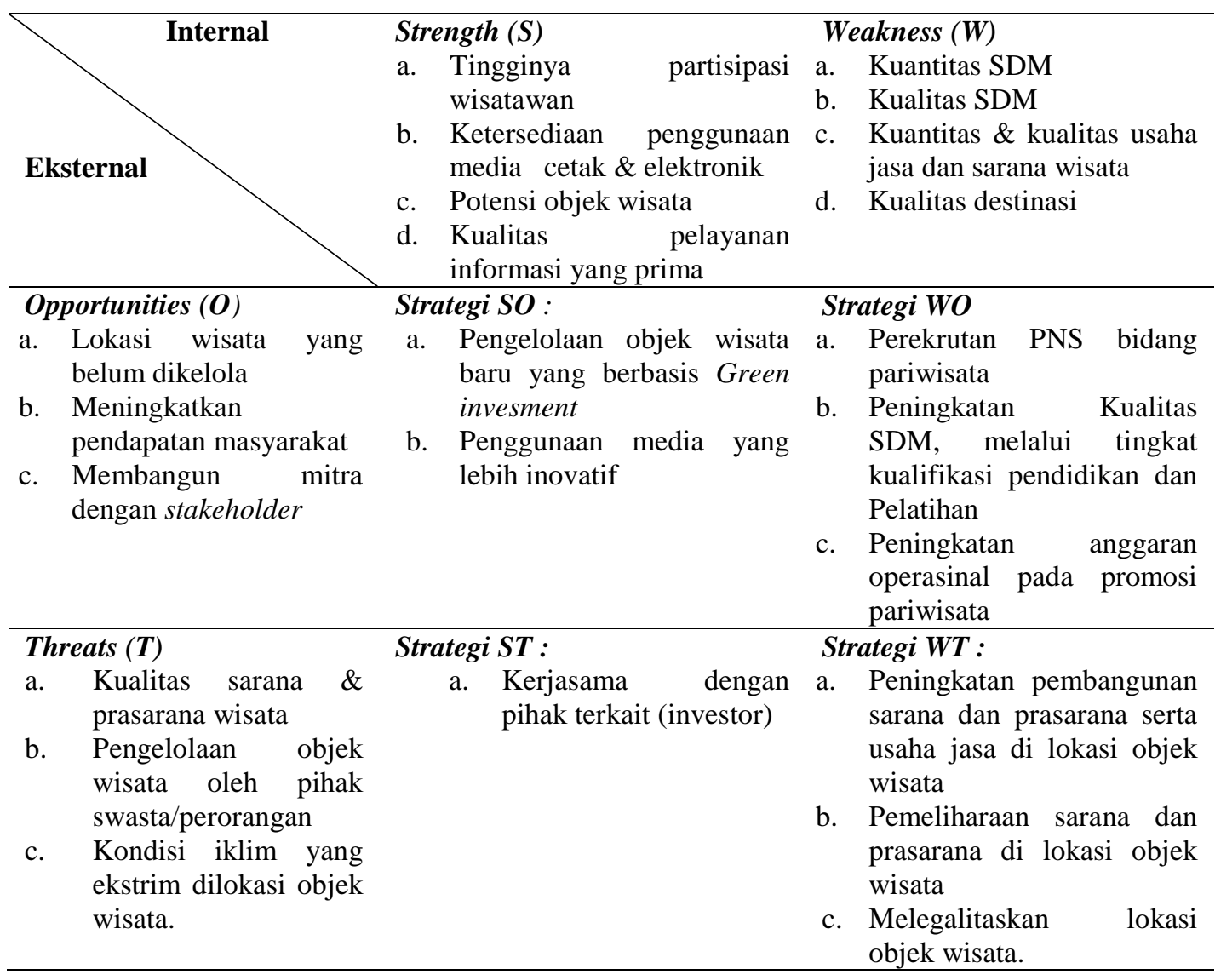

Berdasarkan tabel 2 diatas, mengenai Matriks SWOT perumusan stategi komunikasi pada Dinas Pariwisata dalam promosi objek wisata Kabupaten Banggai, yang menggunakan matriks analisis SWOT dari faktor internal dan eksternal, bahwa kekuatan yang dapat dimanfaatkan untuk merebut dan memanfaatkan peluang (SO), dalam suatu strategi komunikasi oleh Dinas Pariwisata Kabupaten Banggai yakni, pengelolaan objek wisata baru yang berbasis kelestarian lingkungan (green invesment), dan penggunaan media yang lebih inovatif, sehingga hal ini merupakan kekuatan yang dimiliki dapat mengatasi ancaman (ST), dalam upaya untuk mencapai tujuan yang telah ditetapkan seperti halnya melakukan kerjasama dengan pihak terkait (investor), sedangkan peluang yang ditemukan dalam strategi komunikasi ini yang dapat dimanfaatkan untuk meminimalkan kelemahan (WO), yakni; Perekrutan PNS bidang kebudayaan dan pariwisata agar terpenuhinya jabatan struktural pada Dinas Periwisata Kabupaten Banggai, Peningkatan Kualitas SDM melalui tingkat kualifikasi pendidikan dan pelatihan, peningkatan anggaran operasinal pada promosi pariwisata, maka kekuatan yang ada dalam strategi komunikasi dapat 
meminimalkan kelemahan agar dapat terhindar dari ancaman (WT), yakni Peningkatan pembangunan sarana dan prasarana serta usaha jasa di lokasi objek wisata dan pemeliharaan sarana dan prasarana objek wisata, serta melegalitaskan objek wisata, sehingga tercapainya tujuan yang diharapkan pada Dinas Kebudayaan dan Pariwisata Kabupaten Banggai.

\section{Simpulan}

Berdasarkan hasil dan tujuan dalam penelitian ini, yakni untuk mengetahui strategi komunikasi pada Dinas Pariwisata dalam mempromosikan objek wisata Kabupaten Banggai, maka dapat ditarik beberapa kesimpulan bahwa, melihat kondisi lingkungan internal dan eksternal yang dapat dirumuskan pada faktor internal dan eksternal yang indikatornya dapat dikemukakan dalam uraian matriks analisis SWOT dari faktor internal dan eksternal, bahwa Kekuatan yang dapat dimanfaatkan untuk merebut dan memanfaatkan peluang (SO), dalam suatu strategi komunikasi oleh Dinas Pariwisata Kabupaten Banggai yakni, pengelolaan objek wisata baru yang berbasis kelestarian lingkungan (green invesment), dan penggunaan media yang lebih inovatif, sehingga hal ini merupakan kekuatan yang dimiliki dapat mengatasi ancaman (ST), dalam upaya untuk mencapai tujuan yang telah ditetapkan seperti halnya melakukan kerjasama dengan pihak terkait (investor), sedangkan peluang yang ditemukan dalam strategi komunikasi ini yang dapat dimanfaatkan untuk meminimalkan kelemahan (WO), yakni; perekrutan PNS bidang kebudayaan dan pariwisata agar terpenuhinya jabatan struktural pada Dinas Pariwisata Kabupaten Banggai, peningkatan kualitas SDM melalui tingkat kualifikasi pendidikan dan pelatihan, peningkatan anggaran operasinal pada promosi pariwisata, maka kekuatan yang ada dalam strategi komunikasi dapat meminimalkan kelemahan agar dapat terhindar dari ancaman (WT), yakni peningkatan pembangun sarana dan prasarana serta usaha jasa di lokasi objek wisata dan pemeliharaan sarana dan prasarana objek wisata, serta melegalitaskan objek wisata, sehingga tercapainya tujuan yang diharapkan pada Dinas kebudayaan dan Pariwisata Kabupaten Banggai.

Penelitian ini memiliki kontribusi yang penting, karena sebagai karya ilmiah yang dapat menambah khasanah ilmu pengetahuan di bidang ilmu komunikasi khususnya dengan kajian strategi komunikasi dalam mempromosikan objek wisata dan untuk referensi pada tahapan penelitian selanjutnya.

\section{Ucapan Terima Kasih}

Terima kasih kepada Direktorat Riset dan Pengabdian Kepada Masyarakat, Direktorat Jenderal Penguatan Riset dan Pengembangan Kementrian Riset, Teknologi dan Pendidikan Tinggi Republik Indonesia yang telah memberikan dana penelitian melalui skema hibah penelitian dosen pemula (PDP) tahun 2018. 
Suanti Tunggala, Ken Amasita Saadjad: Strategi Komunikasi pada Dinas Kebudayaan dan Pariwisata dalam Mempromosikan Objek Wisata Kabupaten Banggai

\section{Daftar Pustaka}

Burhan, Bungin. (2009). Pengantar Public Relations Strategi menjadi Humas Profesional. Jakarta : Penerbit Ramdina Prakarsa.

Ilmiah, P., Studi, P., Komunikasi, I., Komunikasi, F., Informatika, D. A. N., \& Surakarta, U. M. (2016). Strategi komunikasi pemasaran dalam branding hotel lor in syariah surakarta tahun 2016. Publikasi Ilmiah.

Kementrian Pariwisata dan Ekonomi Kreatif. 2015. Data Kunjungan Wisatawan Mancanegara Tahun 2015.[internet]. [Diunduh tanggal 1 April 2015]. Dapat diunduh dari http://www.parekraf.go.id/userfiles/file/Lapbul\%20Februari\%202015.pdf

Nasrullah, M. (2015). ISLAMIC BRANDING, RELIGIUSITAS DAN KEPUTUSAN KONSUMEN TERHADAP PRODUK. JURNAL HUKUM ISLAM. https://doi.org/10.28918/jhi.v13i2.487

Nurdiani, N. (2014). Teknik Sampling Snowball dalam Penelitian Lapangan. ComTech: Computer, Mathematics and Engineering Applications. https://doi.org/10.21512/comtech.v5i2.2427

Pratiwi, S. R., Dida, S., \& Sjafirah, N. A. (2018). Strategi Komunikasi dalam Membangun Awareness Wisata Halal di Kota Bandung. Jurnal Kajian Komunikasi. https://doi.org/10.24198/jkk.v6i1.12985

Rangkuti, Freddy. (2009). Strategi Promosi yang Kreatif dan Analisis Kasus Integrated Marketing Communication. Jakarta: PT. Gramedia Pustaka Utama.

Rizky, F. M., \& Yasin, H. (2014). PENGARUH PROMOSI DAN HARGA TERHADAP MINAT BELI PERUMAHAN OBAMA PT. NAILAH ADI KURNIA SEI MENCIRIM MEDAN. JURNAL MANAJEMEN \& BISNIS.

Sugiyono. (2012). Metode Penelitian Kuantitatif, Kualitatif Dan Kombinasi (MIXED METHODS). Bandung : Alfabet.

Sugiyono. (2011). Metode Penelitian Kuantitatif, Kualitatif Dan Kombinasi (MIXED METHODS). Bandung : Alfabet.

Sugiyono. (2009). Metode Penelitian Kualitatif. Bandung : Alfabet.

Tami, AI. (2013). Analisis Strategi Komunikasi Pemasaran di Wana Wisata Curug TujuhCilember Cisarua Kabupaten Bogor. [Skripsi]. Bogor (ID) : Institut Pertanian Bogor.

Lukita, Andre., \& Sunarto, Sunarto. (2017). Peran Kementerian Pariwisata Dalam Mengkampanyekan Taman Nasional Komodo Melalui Brand Pesona Indonesia. $\quad$ Prologia, 1 (1). https://journal.untar.ac.id/index.php/prologia/article/view/1330/0

Yunita, Agnes., \& Paramita, Sinta. (2017). Strategi Komunikasi Humas Galeri Nasional Indonesia (Studi Kasus pada Pameran Trienal Seni Patung Indonesia \#3 "SKALA". Prologia, $1 \quad$ (2). https://journal.untar.ac.id/index.php/prologia/article/view/1932/0

N.T., Inggrit Christiani., \& Setyanto, Yugih. (2017). Komunikasi Pariwisata dalam Mempromosikan Objek Wisata Bukit Kasih Kanonang. Prologia, 1 (1). https://journal.untar.ac.id/index.php/prologia/article/view/1368 
Rozi, Rahmat. (2018). Strategi komunikasi pemasaran dinas pariwisata dan kebudayaan. Jurnal Online Mahasiswa Bidang Ilmu Sosial dan Politik. https://jom.unri.ac.id/index.php/JOMFSIP/article/viewFile/18412/17786

Pratiwi, Soraya Ratna., Dida, Susanne., \& Sjafirah, Nuryah Asri. (2018). Strategi Komunikasi dalam Membangun Awareness Wisata Halal di Kota Bandung. Jurnal Kajian Komunikasi, $6 \quad$ (1). https://doi.org/10.24198/jkk.v6i1.12985 